\title{
Biomonitoring of $\mathrm{Zn}$ pollution by using Leaves, Stems and Roots of a Medicinal Plant Centella Asiatica
}

\author{
Yap, C. K., Ong, G. H.
}

Department of Biology, Faculty of Science, Universiti Putra Malaysia, Malaysia

\begin{tabular}{|c|c|}
\hline Article Info & ABSTRACT \\
\hline & \multirow{9}{*}{ 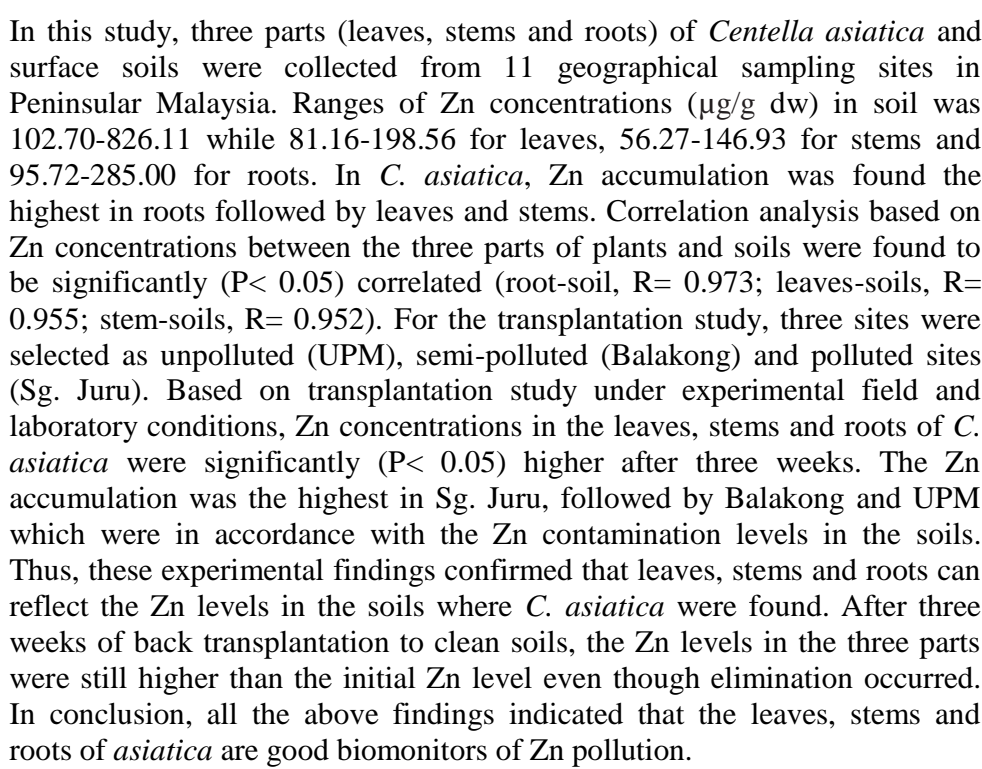 } \\
\hline Received Jun 12, 2014 & \\
\hline Revised Aug 10, 2014 & \\
\hline Accepted Aug 24, 2014 & \\
\hline Keyword: & \\
\hline Centella asiatica & \\
\hline Soils & \\
\hline Transplantation studies & \\
\hline Zinc & \\
\hline
\end{tabular}

Copyright (C) 2014 Institute of Advanced Engineering and Science. All rights reserved.

\section{Corresponding Author:}

Yap, C. K.,

Department of Biology,

Faculty of Science, Universiti Putra Malaysia,

Tel: 603-89466616, Fax: 603-86567454,

43400 UPM, Serdang, Selangor, Malaysia.

Email: yapckong@hotmail.com

\section{INTRODUCTION}

$\mathrm{Zn}$ is one of the most common elements in the Earth's crust. High concentration of $\mathrm{Zn}$ can cause the phytotoxicity which can inhibit metabolic activities and result in growth retardation and senescence in plant. Excessive $\mathrm{Zn}$ can also give rise to $\mathrm{Fe}, \mathrm{Mn}$ and $\mathrm{Cu}$ deficiency that reduce the transfer of those micronutrients from roots to shoots (Ebbs and Kochian, 1997). A medicinal plant Centella asiatica has been used widely in folk medicine for hundreds of years to treat a wide range of illness (Brinkhaus et al., 2000). These plants were used to treat various illnesses thus awareness of the toxic effect of the medication due to the presence of excessive $\mathrm{Zn}$ accumulation shall be of public concern.

In Malaysia, Zn levels have been reported in mussels (Yap et al., 2003) and sediments (Yap and Pang, 2011). However, $\mathrm{Zn}$ levels in terrestrial soils in relation to $C$. asiatica are lacking in the literature. $\mathrm{Zn}$ contamination of natural soil resources can be understand better through this study which has emerged as an important issue due to the extension of urbanization and industrialization in Peninsular Malaysia. The 
objective of this study was to determine the potential of $C$. asiatica as a good biomonitor of $\mathrm{Zn}$ pollution based on correlation of $\mathrm{Zn}$ between the plant and soils and experimental transplantation study.

\section{MATERIALS AND METHODS}

For sampling, a total of 11 sampling sites from around Peninsular Malaysia had been allocated for plant and soil samples collection (Figure 1). The plants of 2-4 months maturity were collected and placed in plastic bags. Then, the surface soil of 3-5 cm depth was collected into a plastic bag using a plastic scoop. Litters in the soil will also be removed. In the laboratory, the plants were separated into leaves, stems and roots.

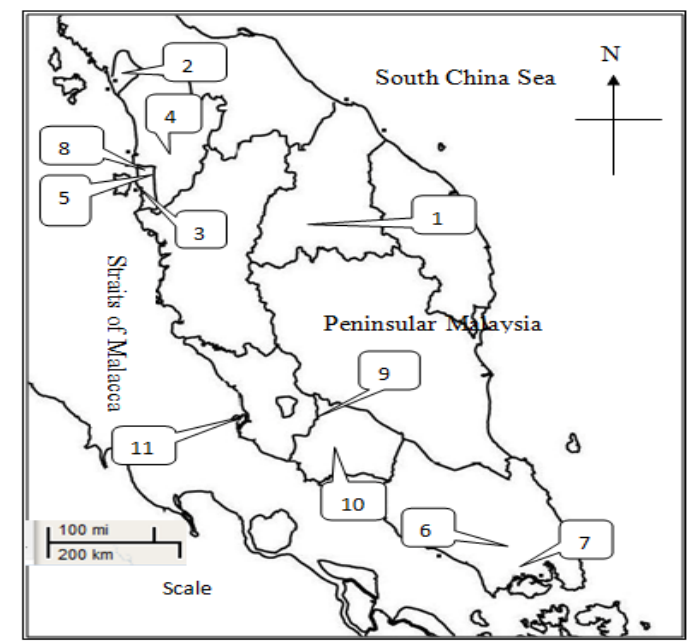

Figure 1. Map showing the sampling sites in Peninsular Malaysia. (Names of samplings sites as in Table 1)

\subsection{Transplantation Study}

For experimental transplantation study, the transplantation studies were carried out both under experimental field and experimental laboratory conditions. For the experiment under field conditions, the plants obtained from University Agricultural Park (Taman Pertanian Universiti, TPU) was planted for two months to reach its maturation stage. Three sites were selected namely Universiti Putra Malaysia (UPM), Balakong and Sg. Juru. Prior to transplantation, soils were collected and determined for $\mathrm{Zn}$ levels. Based on a preliminary study, the $\mathrm{Zn}$ levels $(\mu \mathrm{g} / \mathrm{g} \mathrm{dw})$ in the surface soils were found to be $110.64 \pm 7.77$ for UPM, $362.00 \pm 5.80$ for Balakong, and $500.77 \pm 8.35$ for Sg. Juru. Hence, these sites were categorized as unpolluted, semi-polluted and polluted sites for UPM, Balakong and Sg. Juru, respectively.

For the experimental field condition, the two-months old plants were transferred from UPM (control) to semi-polluted sites at Balakong) and polluted site at Sg. Juru for three weeks (Week 0 to week 3). Then, the plants were back-transplanted from the semi-polluted or the polluted sites to the control site at week 3 and exposed for another 3 weeks (until week 6). For the experimental laboratory conditions, soils from UPM, Balakong and Juru were collected and placed into trays. The soils for the control were taken from the top soil in TPU. At week 0 to week 3, plants from the control trays were transferred to trays containing soils collected from the semi-polluted and polluted sites. From week 3 to week 6 , the plants from semipolluted and the polluted trays were back-transplanted to the unpolluted control trays.

Three replicates were carried out for each site (three traps of $75 \mathrm{~cm} \times 75 \mathrm{~cm}$ for field study and three trays of $60 \mathrm{~cm} \times 35 \mathrm{~cm} \times 10 \mathrm{~cm}$ for laboratory study). The plants were transplanted for every 3 weeks because obvious effect takes place after 2 weeks in transplantation work (U.S.EPA, 1996). The plants were harvested in every 3 weeks.

\subsection{Neutron Activation Analysis (U.S.EPA, 2001; IAEA-TECDOC-1360, 2003)}

The plant and soil samples were dried in an oven at $65^{\circ} \mathrm{C}$ for around 5 days to obtain a constant dry weight $(\mathrm{dw})$. The dried samples were grinded with an electronic agate homogenizer to obtain homogenous powder (about $2 \mathrm{~mm}$ mesh size) to ensure the elements within each samples are uniformly distributed. Then, the samples will be stored in polyethylene bottles for future analysis. For all samples, the homogenous powder samples were shaken manually and has a duplicate weight ranging $0.15-0.20 \mathrm{~g}$ was taken into a 
polyethylene vial and heat-sealed. Certified reference material (CRM) IAEA-SOIL-7 and Pine Needles 1575 a were prepared in identical conditions and used as quality control for each patch. The recovery of $\mathrm{Zn}$ based on CRM were $85.19 \%$ for IAEA-SOIL-7 (CRM certified value: $104.00 \pm 5.20 \mu / \mathrm{g} \mathrm{dw}$; measured value: $88.60 \pm 7.25 \mu / \mathrm{g} \mathrm{dw}$ ) and $111.14 \%$ for Pine Needles $1575 \mathrm{a}$ (CRM certified value: $38.00 \pm 2.00 \mu / \mathrm{g} \mathrm{dw}$; measured value: $42.23 \pm 3.48 \mu / \mathrm{g} \mathrm{dw}$ ).

The irradiations were performed in the TRIGA MARK II reactor at the Agency of Nuclear Malaysia (NUKLEAR MALAYSIA), Bangi, Selangor (Malaysia). Zn is a long lived radioisotope which has 224 days half life. Hence, long irradiation with neutron flux of $4-5 \times 10^{12} \mathrm{n} / \mathrm{cm}^{2}$ was used. After irradiation in the reactor, the radioactivity measurement of the samples were carried out after a proper cooling time by using various close-end coaxial high purity germanium detectors (Model GC3018 CANBERRA Inc and Model GMX 20180, EG4G ORTEC Nuclear Instrument) and their associated electronics. The cooling time for the counting varied between 3-6 days and the live time for the counting of $\mathrm{Zn}$ was 3600 seconds.

\subsection{Concentration Factor}

The concentration factor can be used to determine the uptake of $\mathrm{Zn}$ by plants for transplantation studies. It was calculated according to Yap et al. (2003), as below:

Concentration Factor $=\frac{\mathrm{Zn}_{\text {end of metal accumulation }}}{\mathrm{Zn}_{\text {initial }}}$

The rate of $\mathrm{Zn}$ accumulation was calculated according to a formula (Yap et al., 2003), as below:

Rate of $\mathrm{Zn}$ accumulation $=\frac{\mathrm{Zn}_{\text {exposed }}-\mathrm{Zn}_{\text {initial }}}{\mathrm{Day}(\mathrm{s}) \text { of } \mathrm{Zn} \text { exposure }}$

\subsection{Elimination Factor}

The elimination factor can be used to determine the elimination of $\mathrm{Zn}$ by plants for transplantation studies was calculated according to Yap et al. (2003), as below:

Elimination Factor $=\frac{\mathrm{Zn}_{\text {end of metal elimination }}}{\mathrm{Zn}_{\text {initial }}}$

The rate of Zn elimination was calculated according to the following formula (Yap et al., 2003), as below:

Rate of $\mathrm{Zn}$ elimination $=\frac{\mathrm{Zn}_{\text {exposed }}-\mathrm{Zn}_{\text {initial }}}{\text { Day(s) of } \mathrm{Zn} \text { elimination }}$

\subsection{Statistical Analysis}

The STATISTICA version 8 software was used to determine the correlation coefficient and for hierarchical cluster analysis. The analysis of variance (ANOVA), Student-Newman-Keuls (SNK) and Post hoc test were done using the SPSS software version 17.0 for Windows to find the differences between the mean of heavy metal concentrations in the different parts of the plants from different sites (Zar, 1996).

\section{RESULTS AND DISCUSSION}

\subsection{Zn Levels in Soils}

From Table 1, the Zn level in soils from the 11 sampling sites in Peninsular Malaysia ranges from $102.70 \mu \mathrm{g} / \mathrm{g} \mathrm{dw}$ to $826.11 \mu \mathrm{g} / \mathrm{g} \mathrm{dw}$. The $\mathrm{Zn}$ level in soils from PPauh was significantly $(\mathrm{P}<0.05)$ highest $(826.11 \mu \mathrm{g} / \mathrm{g})$ compared to the other sampling sites.

Based on the soil sediment guidelines for $\mathrm{Zn}$ in Table 2, there are four sampling sites (Arau, Karangan, Pontion and Kepala Batas) were found to be below Chinese soil quality standard $(250 \mu \mathrm{g} / \mathrm{g} \mathrm{dw})$ (CEPA, 1995) and Canadian soil quality for agricultural use (200 $\mu \mathrm{g} / \mathrm{g} \mathrm{dw}$ ) (CCME, 1999). Only three sites at Arau, Karangan, and Pontain were found to be below Target value $(140 \mu \mathrm{g} / \mathrm{g} \mathrm{dw}$, the baseline concentration value that considered not affecting the natural properties of the soil) according to Dutch soil guideline (VROM, 2000). However, only sampling sites Butterworth and Permatang Pauh had Zn levels which are higher than Intervention value $(720 \mu \mathrm{g} / \mathrm{g} \mathrm{dw}$, the maximum tolerable concentration that remediation is required) according to Dutch soil guideline (VROM, 2000). Other sites, except for Senawang, fall around the middle value $(430 \mu \mathrm{g} / \mathrm{g} \mathrm{dw}$, a threshold value for further investigation). 
Table 1. Zn concentrations (mean $\pm \mathrm{SD}, \mu \mathrm{g} / \mathrm{g}$ dry weight) in the soils from 11 sampling sites collected from Peninsular Malaysia

\begin{tabular}{llll}
\hline & Sampling sites & Total Zn & SNK \\
\hline 1. & Wakaf Baru, Kelantan & $408.51 \pm 53.25$ & $\mathrm{c}$ \\
2. & Arau, Perlis & $116.56 \pm 8.66$ & $\mathrm{~d}$ \\
3. & Butterworth, Penang & $793.45 \pm 80.51$ & $\mathrm{a}$ \\
4. & Karangan, Kedah & $124.01 \pm 9.39$ & $\mathrm{~d}$ \\
5. & Permatang Pauh (PPauh), Penang & $826.11 \pm 93.52$ & $\mathrm{a}$ \\
6. & Pontian, Johore & $102.70 \pm 8.46$ & $\mathrm{~d}$ \\
7. & Kempas, Johore & $488.47 \pm 32.35$ & $\mathrm{c}$ \\
8. & Kepala Batas (K.Batas), Penang & $145.90 \pm 10.99$ & $\mathrm{~d}$ \\
9. & Seremban, Sembilan & $643.98 \pm 42.42$ & $\mathrm{~b}$ \\
10 & Senawang, Sembilan & $212.42 \pm 15.04$ & $\mathrm{~d}$ \\
11 & Port Klang, Selangor & $468.51 \pm 32.02$ & $\mathrm{c}$
\end{tabular}

Note: Student-Newman-Keuls (SNK) comparisons of Zn concentrations in soils from all sampling sites. Significant differences $(\mathrm{P}<0.05)$ are shown by different alphabets.

Table 2. Soil quality guidelines for $\mathrm{Zn}$

\begin{tabular}{lll}
\hline Soils Guidelines & & Reference \\
\hline Chinese soil quality standard & 250 & CEPA (1995) \\
Canadian soil quality guidelines for agricultural & 200 & CCME (1999) \\
Dutch soil guidelines-Target value & 140 & VROM (2000) \\
Dutch soil guidelines-Intervention value & 720 & VROM (2000) \\
Dutch soil guidelines-Middle value & 430 & VROM (2000) \\
\hline
\end{tabular}

Note: All values are presented in $\mu \mathrm{g} / \mathrm{g}$ dry weight

In polluted sites, the $\mathrm{Zn}$ concentrations are found in the range of $150-300 \mu \mathrm{g} / \mathrm{g}$ in soils has been reported (Warne et al., 2008). It is widely reported anthropogenic activities had increased the levels of $\mathrm{Zn}$ in soils. Malaysia has well developed industrial areas with massive production of electronic products. Industries in Malaysia such as electronics, textiles, food processing and rubber based industry contribute the $\mathrm{Zn}$ contamination to the environment (Alkarkhi et al., 2009). The use of fungicides and fertilizers containing organo-zinc could have caused the excess to leach into the soil (WHO, 2001). Soils near highways and smelters contained high $\mathrm{Zn}$ concentrations as a result of deposition of $\mathrm{Zn}$ released in tire abrasion and stack emissions (Norrström and Jacks, 1999). Zn level in soils was reported decreased with distance from the point source of pollution (CCME, 1999). Therefore, higher level of $\mathrm{Zn}$ can be found in nearby of the $\mathrm{Zn}$ contamination source.

Mean $144.10 \mu \mathrm{g} / \mathrm{g}$ dw of $\mathrm{Zn}(53 \mu \mathrm{g} / \mathrm{g}$ dw to $380 \mu \mathrm{g} / \mathrm{g} \mathrm{dw})$ has been reported by Wang and Qin (2007) in urban topsoil of Xuzhou, China. According to Yap and Pang (2011), 88.7-484.1 $\mu \mathrm{g} / \mathrm{g}$ dw of Zn was found in river drainage surface sediments collected from the north western aquatic area of Peninsular Malaysia. 50$336 \mu \mathrm{g} / \mathrm{g}$ and 330-484 $\mu \mathrm{g} / \mathrm{g}$ of Zn was reported by Yap et al. (2008) and Yap et al. (2007) from intertidal and drainages in Selangor and polluted drainage sediments from Peninsular Malaysia. Those reading was lower compared to our study might be due to different nearby human activities. Therefore more concern about $\mathrm{Zn}$ contamination should be shown by the public in Malaysia especially for agricultural purpose.

\subsection{Zn Levels in Plants}

The $\mathrm{Zn}$ levels in the three parts of $C$. asiatica from 11 sampling sites are presented in Figure 2 . $\mathrm{Zn}$ concentrations ranged from 81.16 to $198.56 \mu \mathrm{g} / \mathrm{g} \mathrm{dw}$ for leaves, $56.27-146.93 \mu \mathrm{g} / \mathrm{g} \mathrm{dw}$ for stems and 95.72 $285.00 \mu \mathrm{g} / \mathrm{g} \mathrm{dw}$ for roots. PPauh, K.Batas and Senawang showed the highest $\mathrm{Zn}$ accumulations in roots while K.Batas in leaves was the highest. In stems, K.Batas, Wakaf Baru and Senawang were found the highest in Zn levels.

From all the sampling sites, the roots showed the highest $\mathrm{Zn}$ accumulation followed by leaves and stems (Figure 2). Those results were supported by Yap et al. (2010). Around $30 \mu \mathrm{g} / \mathrm{g} \mathrm{dw}$ of $\mathrm{Zn}$ is adequate for plant growth and 300 to $500 \mathrm{mg} / \mathrm{kg}$ of $\mathrm{Zn}$ is considered toxic to the plants (Miransari, 2011). The physiological disorders and metabolic abnormalities in plants occur when exposed excessive of $\mathrm{Zn}$ accumulations (Singh, 2007). Hence, Zn might be accumulated in the roots and be unable to enter the plant by being kept in the root cells where they would be detoxified by forming complexes or sequestered into vacuoles (Hall 2002). This action greatly restricted the translocation of metals to the above-ground organs. Moreover, it could protect the leaf tissues and the metabolically active photosynthetic cells from heavy metal damage (Sgherri et al., 2003). 

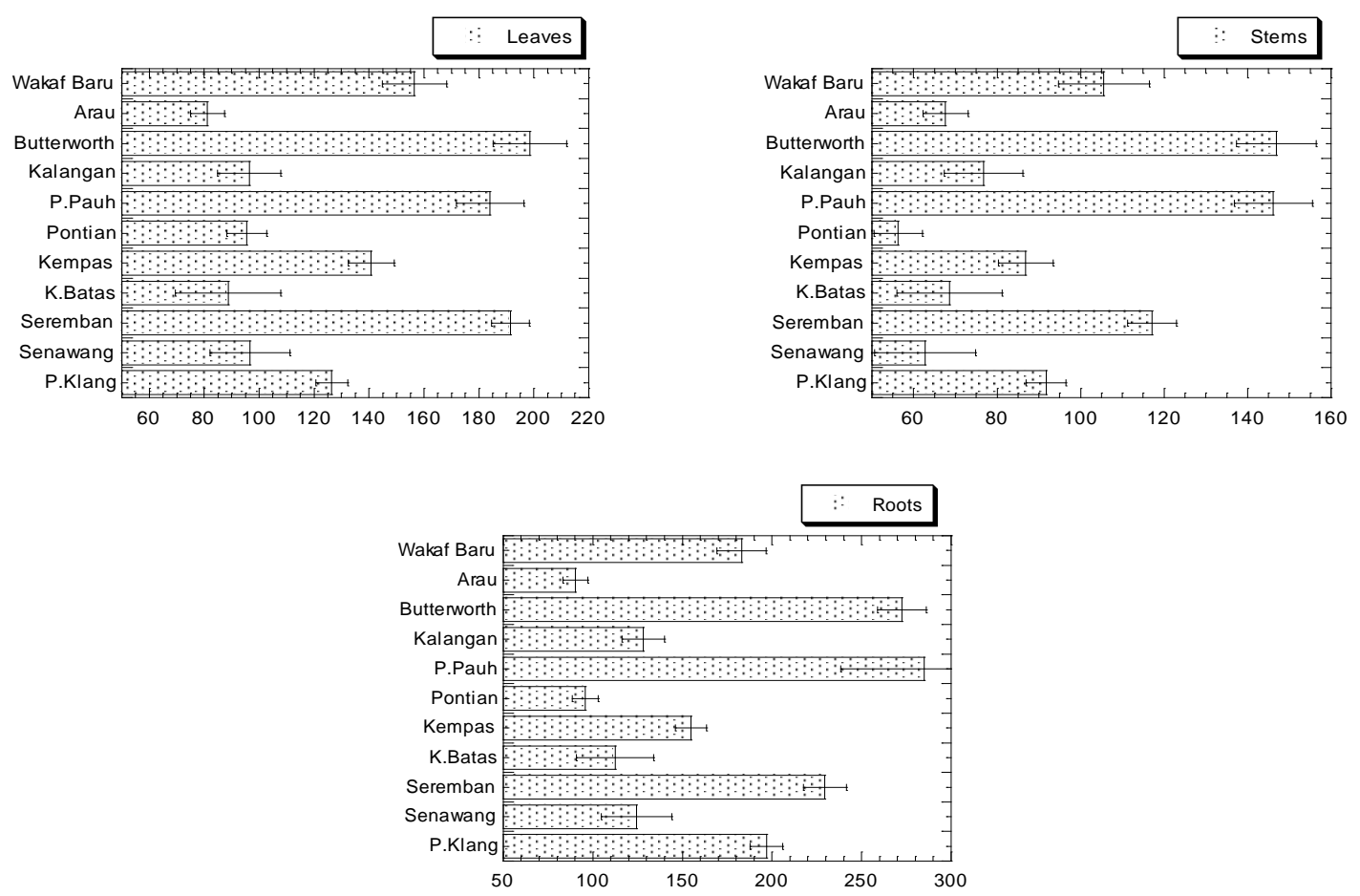

Figure 2. Concentrations (mean $\pm \mathrm{SD}, \mu \mathrm{g} / \mathrm{g} \mathrm{dw}$ ) of in leaves, stems and roots of Centella asiatica collected from 11 sampling sites from Peninsular Malaysia

In the roots of $P$ Phragmite australis, $\mathrm{Zn}$ levels were found with $104.10 \mu \mathrm{g} / \mathrm{g} \mathrm{dw}$ followed by rhizomes $(32.67 \mu \mathrm{g} / \mathrm{g} \mathrm{dw})$, leaves $(28.40 \mu \mathrm{g} / \mathrm{g} \mathrm{dw})$ and stems $10.04 \mu \mathrm{g} / \mathrm{g} \mathrm{dw})$ (Bonanno and Giudice, 2010). According to Serbula et al. (2012), Robinia pseudoacacia can deposit around $118.4 \mu \mathrm{g} / \mathrm{g} \mathrm{dw}$ of $\mathrm{Zn}$ in leaves. In $C$. asiatica, $167.74 \mu \mathrm{g} / \mathrm{g} \mathrm{dw}$ of $\mathrm{Zn}$ was found in roots followed by leaves $(131.56 \mu \mathrm{g} / \mathrm{g} \mathrm{dw})$ and stems $(92.65 \mu \mathrm{g} / \mathrm{g} \mathrm{dw})$. From the studies mention above, Zn levels in $C$. asiatica were similar with the reported mention above. These indicate that $C$. asiatica can tolerance high level of $\mathrm{Zn}$ where the accumulation of $\mathrm{Zn}$ was more than $30 \mu \mathrm{g} / \mathrm{g} \mathrm{dw}$ of $\mathrm{Zn}$ that adequate for plant (Miransari, 2011). However, the accumulation did not exceed the toxic level reported by Miransari (2011).

\subsection{Correlations of $\mathrm{Zn}$ between Plant and Soils}

Based on Figure 3, the correlation coefficients of $\mathrm{Zn}$ between plants and soils were found the highest between root-soil $(\mathrm{R}=0.973, \mathrm{P}<005)$, followed by leaves-soils $(\mathrm{R}=0.955, \mathrm{P}<005)$ and stem-soils $(\mathrm{R}=0.952$, $\mathrm{P}<005)$. The above results indicate the three parts of $C$. asiatica are able to reflect the $\mathrm{Zn}$ levels in the soils. Therefore, the roots, leaves and stems of $C$. asiatica are good biomonitors of $\mathrm{Zn}$ contamination.
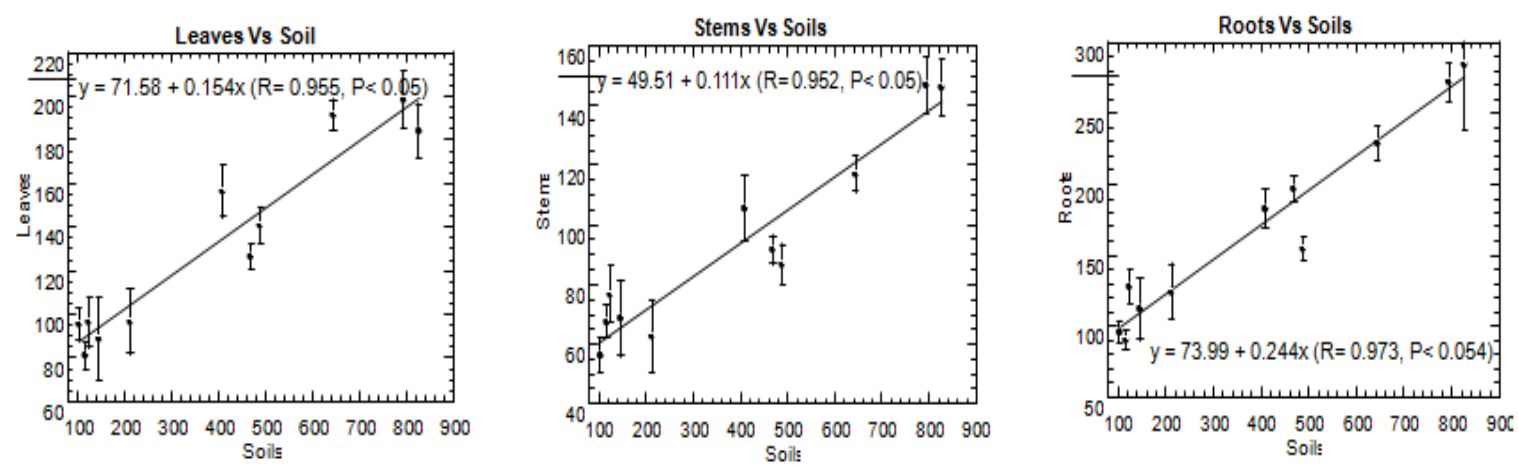

Figure 3. Relationships of $\mathrm{Zn}$ between the Centella asiatica (leaves, stems and roots) and soils, based on 11 sampling sites 


\section{EXPERIMENTAL TRANSPLANTATION STUDIES}

For the transplantation study (Figure 4), the accumulation of $\mathrm{Zn}$ increased for all parts when transplanted from control to semi-polluted and polluted sites under field condition (week 0 to week 3 ). The increases were highest for Juru followed by Balakong in leaves, stems and roots. However, the accumulation decreased (week 3 to week 6) after transplantation from the semi-polluted and polluted sites back to the control sites. The accumulation was still highest in Juru followed by Balakong. The trend in transplantation study under laboratory conditions was exactly similar to the transplantation study under field conditions with slightly lower concentrations of Zn was accumulated (Figure 4).

Field
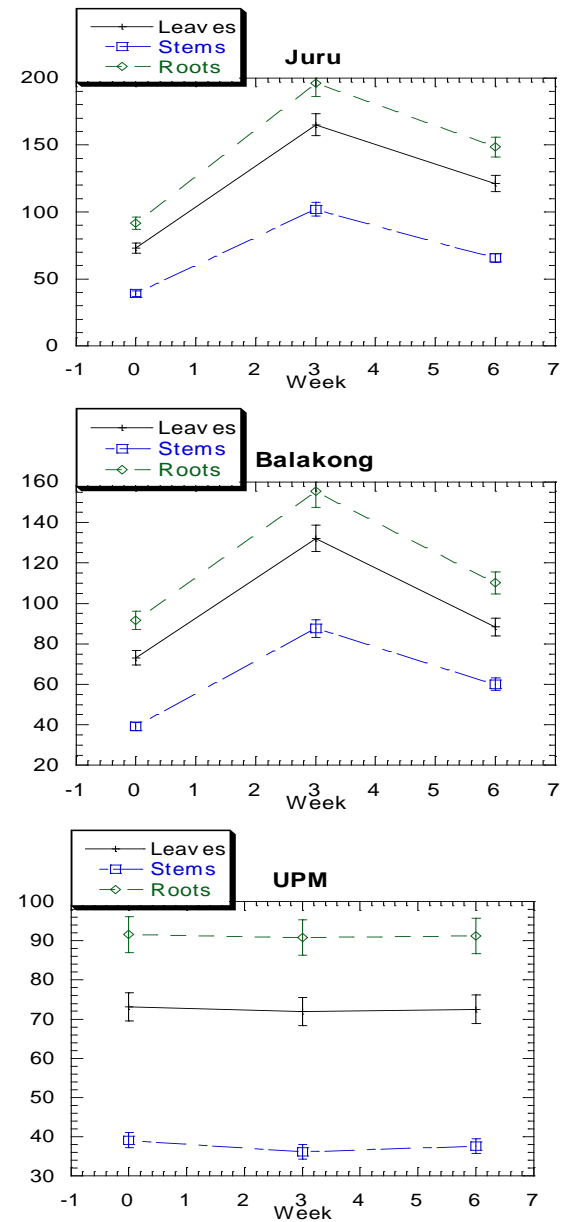

$<$-Accumulation--><-- elimination->
Laboratory
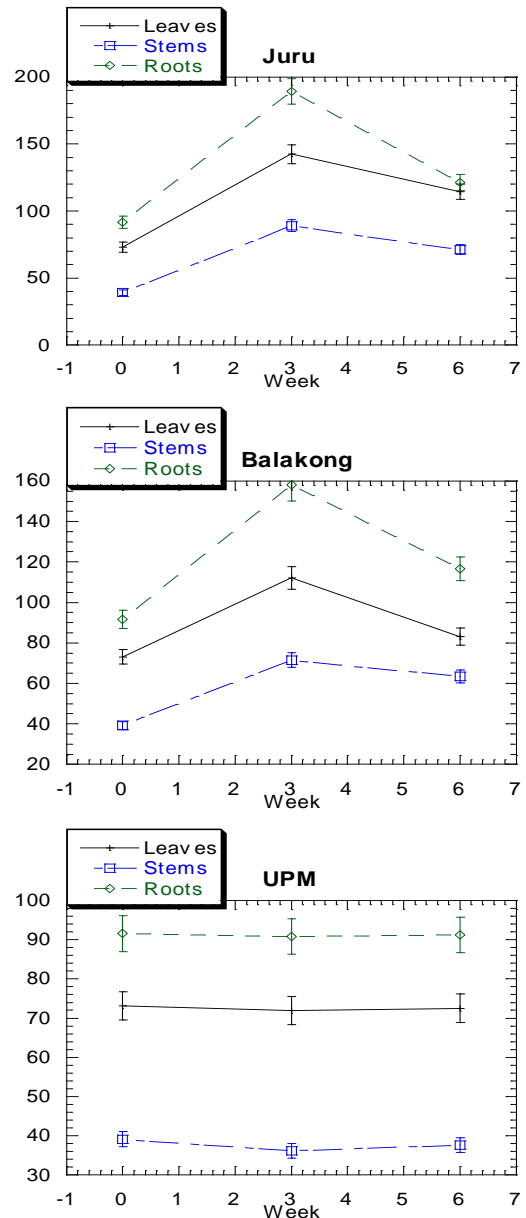

$<-$ Accumulation--><-- elimination->

Figure 4. Concentrations (mean $\pm \mathrm{SD}, \mu \mathrm{g} / \mathrm{g}$ dry weight) of $\mathrm{Zn}$ in leaves, stems and roots of Centella asiatica for transplantation work during accumulation (weeks 1-3) and elimination (weeks 4-6) under experimental field and laboratory conditions

Table 3. Zn concentration factors, rates of $\mathrm{Zn}$ accumulation, $\mathrm{Zn}$ elimination factor, rates of $\mathrm{Zn}$ elimination in the transplanted Centella asiatica under experimental field and laboratory conditions

\begin{tabular}{llllllll}
\hline & \multirow{2}{*}{ Sites } & \multicolumn{3}{c}{ Field condition } & \multicolumn{3}{c}{ Laboratory condition } \\
& & Leaves & Stems & Roots & Leaves & Stems & Roots \\
\hline Concentration factor & Sg. Juru & 2.26 & 2.61 & 2.14 & 1.95 & 2.28 & 2.07 \\
& Balakong & 1.81 & 2.24 & 1.7 & 1.53 & 1.83 & 1.73 \\
Rate of accumulation $(\mu \mathrm{g} / \mathrm{g}$ per day) & Sg. Juru & 0.73 & 0.64 & 0.76 & 0.8 & 0.8 & 0.64 \\
& Balakong & 0.67 & 0.69 & 0.71 & 0.74 & 0.89 & 0.74 \\
Elimination factor & Sg. Juru & 4.39 & 3 & 4.98 & 3.3 & 2.38 & 4.65 \\
& Balakong & 2.81 & 2.31 & 3.04 & 1.86 & 1.54 & 3.17 \\
Rate of Elimination $(\mu \mathrm{g} / \mathrm{g}$ per day) $)$ & Sg. Juru & 2.1 & 1.73 & 2.27 & 1.33 & 0.85 & 3.23 \\
& Balakong & 2.09 & 1.31 & 2.15 & 1.38 & 0.38 & 1.97 \\
\hline
\end{tabular}


From Table 3, the overall for the concentration factor and rate of accumulation were highest for Juru under field and laboratory conditions. The elimination factor was highest for Juru and rate of elimination was fastest for Juru.

All the samples in transplantation studies (Figure 4) showed a similar trend as for all the wild samples from the 11 sampling sites (Figure 2) that roots had the highest $\mathrm{Zn}$ accumulation followed by leaves and stems. In Figure 3, the accumulation of $\mathrm{Zn}$ increased for all parts when transplanted from control to semipolluted and polluted sites in field conditions (week 0 to week 3 ).

All concentration factors in $C$. asiatica were greater than 1 indicating that the plants were able to uptake high levels of $\mathrm{Zn}$. In 3 week's time, the plants were able to uptake more than $100 \%$ higher than the initial value (Table 3). The $C$. asiatica can be chosen as an ideal biomonitor due to its tolerance to exposure in the environment. The rate of accumulation was high where ranging $0.60-0.89 \mu \mathrm{g} / \mathrm{g}$ per day. Therefore, the plants can reflect the $\mathrm{Zn}$ contamination by their accumulation levels. The most important of all is its capability as net accumulators of the metal over a short time period (Rainbow and Phillips, 1993). The accumulation of $\mathrm{Zn}$ decreased (week 3 to week 6) after transplantation back to the control site even though the accumulation was higher than at the control site. For the transplantation under laboratory conditions, the trend was same as the transplantation under field conditions (Figure 3). This shows that the transplantation studies under laboratory condition reflect the transplantation studies under field condition.

Based on Table 3, the elimination factor for field and laboratory conditions were at least $154 \%$ for all parts with elimination factor ranging from 1.54 to 4.98 . This indicated that $\mathrm{Zn}$ could be eliminated from plants when transplanted to less contamination sites. Oxidative stress caused by Zn was well documented by Smirnoff (1998). It would increase the ROS level within the subcellular compartments of the cell (Mittler et $a l ., 2004)$. Hence, the plant will try to eliminate excess $\mathrm{Zn}$ from the plant to prevent phytotoxicity caused by high $\mathrm{Zn}$ levels. Zn accumulated in excess in plant tissues will causes alterations in vital growth processes such as photosynthesis and chlorophyll biosynthesis (Doncheva et al., 2001). An excess of $\mathrm{Zn}$ has been reported to have a negative effect on mineral nutrition (Chaoui et al., 1997).।

By comparing the accumulation (week 0-3) and the depuration (week 3-6) of $\mathrm{Zn}$ in Figure 3, the accumulation in the laboratory was slightly lower than those transplanted under field conditions even though the soils were obtained from the same sites. This was due to the continuous supply of Zn contamination from nearby activities in semi-polluted or polluted sites. However, the levels of $\mathrm{Zn}$ in plants were not significantly different $(\mathrm{P}<0.05)$ between field and laboratory studies for Balakong and Juru. This might be due to $\mathrm{Zn}$ not being significant added from the source into soils for particular sites.

When comparing between week 0 and week 6, higher $\mathrm{Zn}$ was found in the back-transplanted plant in week 6 than in week 0 in that they were far from reaching the initial $\mathrm{Zn}$ concentration (week 0). This could be due to the accumulation being dependent on the transplantation period. This indicated that the eliminations of $\mathrm{Zn}$ were not complete during the three weeks of transplantation for $C$. asiatica. Therefore, a longer time is required for the elimination of $\mathrm{Zn}$ in plants.

\section{CONCLUSION}

From the present results, it was found that that significant correlation of $\mathrm{Zn}$ between $C$. asiatica and soils were found. This indicated that roots, leaves and stems are able to reflect the $\mathrm{Zn}$ pollution of the sampling sites. The positive results based on experimental studies under field and laboratory conditions confirmed the use of roots, leaves and stems as good biomonitor of $\mathrm{Zn}$ pollution.

\section{ACKNOWLEDGMENTS}

The authors wish to acknowledge the financial support provided through Research University Grant Scheme (RUGS) [Vote no. 9322400] by Universiti Putra Malaysia.

\section{REFERENCES}

[1] Alkarkhi A. F., et al., "Analysis of heavy metal concentrations in sediments of selected estuaries of Malaysia-a statistical assessment," Environ. Monit. Assess, 2009, Vol. 153, pp. 179-185.

[2] Bonanno G., et al., "Heavy metal bioaccumulation by the organs of Phragmites australis (common reed) and their potential use as contamination indicators," Ecol. Ind. 2010, Vol. 10, pp. 639-645.

[3] Brinkhaus B., et al., "Review Article: Chemical, pharmacological and clinical profile of the East Asian medical plant Centella asiatica." Phytomedicine. 2000, Vol. 7, No. 5, pp. 427-448.

[4] "CCME (Canadian Council of Ministers of the Environment)," Canadian Environmental Quality Guidelines. Canadian Council of Ministers of the Environment, Winnipeg, Manitoba, 1999. 
[5] CEPA, "Environmental quality standard for soils (GB 15618-1995) (in Chinese)," Chinese Environmental Protection Administration, 1995.

[6] Chaoui A., et al., "Cadmium and zinc induction of lipid peroxidation and effects on antioxidant enzyme activities in bean (Phaseolus vulgaris L.)," Plant Sci., 1997, Vol. 127, pp. 139-147.

[7] Doncheva S., et al., "The influence of succinate on zinc toxicity of pea plant," J. Plant Nutr, 2001, Vol. 24, pp. 789-806.

[8] Ebbs S. D., et al., "Toxicity of zinc and copper to Brassica species: Implications for phytoremediation,” J. Environ. $Q ., 1997$, Vol. 26, pp. 776-781.

[9] Hall J. L., "Cellular mechanisms for heavy metal detoxification and tolerance," J. Exp. Bot,. 2002, Vol. 53, pp. 111.

[10] IAEA-TECDOC-1360, "Collection and preparation of bottom sediment samples for analysis of radionuclides and trace elements, IAEA, Vienna. 2003.

[11] Miransari M., "Hyperaccumulators, arbuscular mycorrhizal fungi and stress of heavy metals," Biotech. Adv. 2011, Vol. 29, pp. 645-653.

[12] Mittler R., et al., "Abiotic stress series. Reactive oxygen gene network of plants," Trends Plant Sci. 2004, Vol. 9, No. 10, pp. 490-498.

[13] Norrstrom A. C., et al., "Concentration and fractionation of heavy metals in roadside soils receiving de-icing salts," Sci. Tot Environ, 1998, Vol. 218, pp. 161-174.

[14] Rainbow P. S., et al., "Cosmopolitan biomonitors of trace metals," Mar. Pollut. Bull. 1993, Vol. 26, pp. 593-601.

[15] Serbula S. M., et al., "Assessment of airborne heavy metal pollution using plant parts and topsoil," Ecotox. Environ. Saf. 2012, Vol. 76, pp. 209-214.

[16] Sgherri C., et al., "Phenols and antioxidative status of Raphanus sativus grown in excess copper," Physiol. Plantarum, 2003, Vol. 118, pp. 21-28.

[17] Singh B.K., "Studies on variability and heterosis of important economic and nutritive traits in cabbage," Ph.D. Thesis. IARI, Pusa, New Delhi, India, 2007.

[18] Smirnoff N., "Plant resistance to environmental stress," Curr. Opin. Biotechnol, 1998, Vol. 9, pp. $214-219$.

[19] U.S. EPA., "Ecological effects test guidelines (Public draft)," U.S. Environmental Protection Agency, Washington, DC, EPA, 1996.

[20] U.S. EPA., "Methods for collection, storage and manipulation of sediments for chemical and toxicology," Office of Water. U.S. Environmental Protection Agency. Washington, DC, 2001.

[21] VROM, "Circular on target values and intervention values for soil remediation Annex A: target values, soil remediation intervention values and indicative levels for serious contamination," Dutch Ministry of Housing, Spatial Planning and Environment, 2000.

[22] Wang X. S., et al., "Some characteristics of the distribution of heavy metals in urban topsoil of Xuzhou, China," Environ. Geochem. Health, 2007, Vol. 29, No. 1, pp. 11-19.

[23] Warne M. S. J., et al., "Modelling the 181 toxicity of copper and zinc salts to wheat in 14 soils," Environ. Toxicol. Chem. 2008, Vol. 27, pp. 786-792.

[24] WHO, "Zinc. Environmental Health Criteria 221," World Health Organisation, International Programme on Chemical Safety (IPCS), Geneva, Switzerland, 2001.

[25] Yap C. K., et al., "Cd and $\mathrm{Zn}$ in the straits of Malacca and intertidal sediments of the west coast of Peninsular Malaysia," Mar. Poll. Bull, 2003, Vol. 46, pp. 1348-1353.

[26] Yap C. K., et al., "Assessment of $\mathrm{Cu}, \mathrm{Pb}$, and $\mathrm{Zn}$ contamination in sediment of north western Peninsular Malaysia by using sediment quality values and different geochemical indices," Environ. Monit. Assess, 2011, Vol. 183, pp. 23-39.

[27] Yap C. K., et al., Distribution of $\mathrm{Ni}$ and $\mathrm{Zn}$ in the surface sediments collected from drainages and intertidal area in Selangor," Pertanika J. Trop. Agric. Sci, 2008, Vol. 31, No. 1, pp. 79-89.

[28] Yap C. K., et al., "Effect of metal-contaminated soils on the accumulation of heavy metal in different parts of Centella asiatica: A laboratory study," Sains Malay, 2010, Vol. 39, pp. 347-352.

[29] Yap C. K., et al., "Heavy metal ( $\mathrm{Cd}, \mathrm{Cu}, \mathrm{Ni}, \mathrm{Pb}$ and $\mathrm{Zn}$ ) pollution in surface sediments collected from drainages receiving different anthropogenic sources from Peninsular Malaysia,” Wetland Sci, 2007, Vol. 5, No. 2, pp. $97-$ 104.

[30] Zar J. H., "Biostatistical analysis,” 3rd. ed. Prentice Hall, New Jersey, 1996. 